\title{
Friendly fire
}

2006, I have decided, is the year that I'll make it big. I'll get a promotion. I'll be wildly popular. And in order to do this I'll meet lots of people and make them my friends.

So imagine my delight when I find a study about networking in my inbox at the start of the week. It sounds like a large and impressive investigation...

The two guys behind the research, at Columbia University in New York, decided to analyse how people interact with each other. So they sifted through some 14 million e-mail messages sent by more than 43,000 students and staff in a large university (an institution that they decline to name, although I have my suspicions).

They spent three years or so building and running fiendish computer algorithms that could analyse who had e-mailed whom and how often.

The stunning conclusion? Two people are more likely to strike up a relationship if they go to the same college class or have a friend in common.

Brilliant, I think. Genius. It took years sorting though countless messages to work that out? There must be more to this than meets the eye: I pick up the phone to find out.

Quantity not quality

Naturally, Columbia's Duncan Watts is quick to reassure me that his study has hidden depths: it's all about quantification. For example, I suspect that I'm more likely to meet a friend of a friend, than a friend of a friend of a friend, and the study shows this is true. But it also reveals that the former is 30 times more likely than the latter.

These numbers, apparently, are gold dust for the sociologists who hope to devise models of how people behave.

Some say such models could show public-health officials how to quench an epidemic, or viral marketers how to spark one. Ultimately, they might help us understand those heavyweight questions of how people form societies or religions.

\section{Solid stuff}

Of course, these grand schemes are probably a bit far-off. But the study did have something of more concrete use in my plan for social domination.

As a whole, the spaghetti junction of relationships linking all the students in the study changed surprisingly little over the academic year. While one person was busy making new friends, another was busy dropping them. The people who are most connected one day may be less connected the next.

So my resolution to schmooze is probably pointless: for all I know, my new friends are about to sever the very ties and influence I covet in them.

To be honest, this comes as a relief. I'm more comfortable being the cynical loner.

And it leaves me plenty of time to look into the stories behind some of these other bizarre, seemingly pointless science headlines. Just stick around. I'll be back.

\section{"Sybil":mailto:sybil@nature.com writes exclusively for news@nature.com. Her column will be appearing regularly on our} site.

\section{Post a comment to this story by visiting our bebluntfriendlyfire.html">newsblog.}

\section{References}

1. Kossinets G., Watts D.J., et al. Science, 311. 88 - 90 (2006). 